\title{
Agriculture, Climate Change and Food Security
}

\author{
Nehemia Kiprutto, Laban K. Rotich, Geoffrey K. Riungu \\ School of Tourism, Hospitality and Events Management, Moi University, Eldoret, Kenya \\ Email: sirlurburn@gmail.com
}

Received 27 April 2015; accepted 12 May 2015; published 22 May 2015

Copyright (C) 2015 by authors and OALib.

This work is licensed under the Creative Commons Attribution International License (CC BY). http://creativecommons.org/licenses/by/4.0/

(c) (i) Open Access

\begin{abstract}
Agriculture is one of the main economic activities in the world, with its significance magnified especially among the world's poor. This paper seeks to explore how climate change would impact on the agricultural sector and consequently food security. Agricultural activities in most developing countries entirely depend on rainfall patterns, on the contrary, climate change has emerging as an environmental challenge with adverse impacts expected on food security. This is mainly through incidences of changes in water availability, floods and drought. For example, changes in temperature and precipitation including drought affects crop and livestock yield, hydrologic balances, input supplies and other components of agricultural systems. Equally important, environmental degradation is one of the drivers of climate change that further undermines sustainability of agriculture. Climate change is real and already taking place. According to the inter-governmental panel on climate change (IPCC), warming temperatures are projected to cause more frequent and more intense extreme weather events such as heavy rain storms, flooding and tropical storms and in some cases drought in many parts of the country. Agriculture is one of the most climate sensitive sectors, with projections that $\mathbf{8 0 0}$ million people are currently food insecure. Additionally, it has the potential to undermine advances in poverty reduction and sustainable development. Thus, fundamental changes in agricultural systems are needed because climate change poses new and serious challenges for farmers hence food insecurity. Most important, agricultural adaptation and mitigation pathways need to be developed so as to avoid further threat on food security.
\end{abstract}

\section{Keywords}

Agriculture, Climate Change, Extreme Events, Food Security

Subject Areas: Education

\section{Introduction}

Agriculture constitutes the backbone of most African economies. It is the largest contributor to GDP; the biggest

How to cite this paper: Kiprutto, N., Rotich, L.K. and Riungu, G.K. (2015) Agriculture, Climate Change and Food Security. Open Access Library Journal, 2: e1472. http://dx.doi.org/10.4236/oalib.1101472 
source of foreign exchange, accounting for about $40 \%$ of the continent's foreign currency earnings; and the main generator of savings and tax revenues. In addition, about two-thirds of manufacturing value-added is based on agricultural raw materials. Agriculture remains crucial for pro-poor economic growth in most African countries, as rural areas support $70 \%-80 \%$ of the total population [1]. On the contrary, climate change is considered as posing the greatest threat to agriculture and food security in the 21st century, especially in many poor, agriculture-based countries of sub-Saharan Africa (SSA) with their low capacity to effectively cope [2] [3]. Most important, African agriculture is already under stress as a result of population increase, industrialization and urbanization, competition over resource use, degradation of resources, and insufficient public spending for rural infrastructure and services, yet the impact of climate change is likely to exacerbate these stresses even further [1]. Therefore, the global agricultural industry will have to meet the demands of food from rising populations in the face of degraded soil and water stress as a result from climate change. Special attention goes to the fact that, agricultural productivity needs to be increased in order to meet the demand of the growing population in the present and coming decades, this means more water is already a challenge because of its scarcity and competition for it.

Also, the United Nations Development Programme [4] warns that the progress in human development achieved over the last decade may be slowed down or even reversed by climate change, as new threats emerge to water and food security, agricultural production and access, and nutrition and public health [1].

Equally important, the impacts of climate change include; sea level rise, droughts, heat waves, floods and rainfall variation which could by 2080, push another 600 million people into malnutrition and increase the number of people facing water scarcity by 1.8 billion [4]. A number of countries in Sub-Saharan Africa (SSA) are already experiencing considerable water stress as a result of insufficient and unreliable rainfall, changing rainfall patterns or flooding. Similarly, the impacts of climate change including predicted increases in extremes are likely to add to this stress, leading to additional pressure on water availability, accessibility, supply and demand [1] (Table 1).

\section{Materials and Methods}

This paper builds on recent reports of climate change effects on agriculture and food security [1] [5]. Majority of the information relating directly and indirectly to agriculture, climate change and food security were sourced from published articles using the following keywords; agriculture, climate change and food security. In addition, the various reports were carefully reviewed and were found authentic. Also, majority of the findings from the published articles expressed deep concerns about climate change impacts on agriculture, posing serious threats to food security especially in developing countries. Moreover, future predictions indicated food insecurity in developing countries including Kenya coupled with extreme weather events such as droughts, floods and rising temperatures. However, the articles strongly underscored mitigation pathways and adaptation strategies as solutions that would play a major and critical role in reducing climate change impacts on agriculture including food security. All the articles were published between the years (1996-2009).

The possible causes of food insecurity coupled with climate change effects on agriculture were summarized in a tabular form. Problem analysis was performed using a fishbone chart approach to identify climate change impacts on agricultural production and food security. The fishbone chart approach explained through the fishbone diagram (Figure 1), also known as cause and effect diagram refers to an orderly chart that categorizes the many potential causes in a problem in an orderly way. It was invented by Kaoru Ishikawa in 1943, further; spacecraft engineers have been using these diagrams for many years to diagnose mechanical problems [6]. The table provides a comprehensive view of future food security situations comprised with agricultural yield output in the face of climate change negative impacts. This method strives to highlight climate change influence on agricultural production as well as food security, identified from the reviewed reports, and aided in the development of a framework that provides the basis for future detailed investigations and experiments.

\section{Agriculture and Climate Change}

Although the different climate change models are not clear with respect to rainfall and periods of drought, temperature projections are generally more reliable. Increased evaporation and evapotranspiration with associated soil moisture deficits will impact rain fed agriculture [7]. Similarly, fertilizer application (agricultural soils), livestock and manure management, rice cultivation, savanna clearing and burning of agricultural residues are ma- 


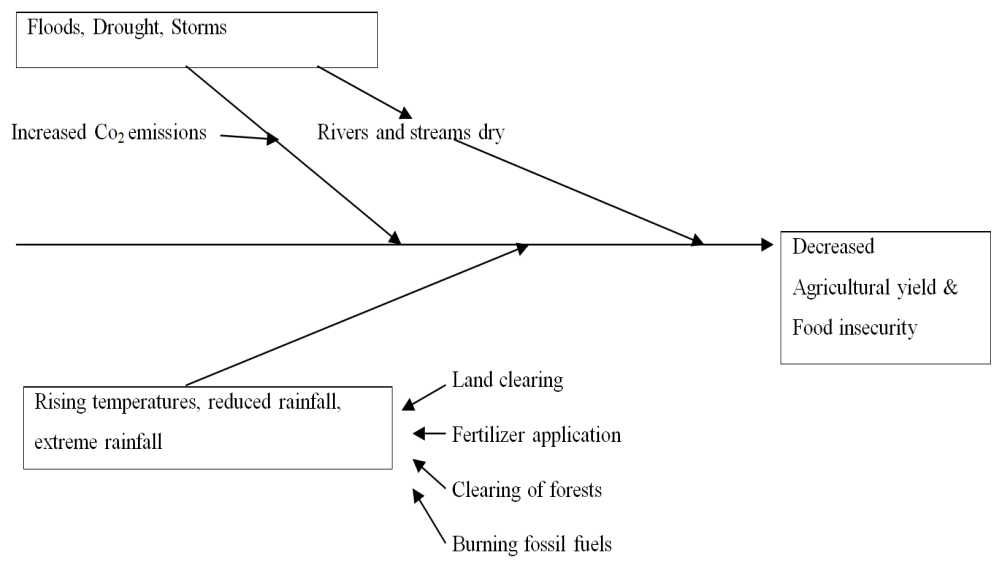

Figure 1. Cause effect model for climate change impacts on agriculture and food security. Source: Author, 2014.

Table 1. Articles on impacts of climate change on agriculture and food insecurity.

Source (Main Content) Article \& Findings

World Food Programme (WFP) August, 2009: Kenya in need of access to emergency food assistance—Kenya is food insecure

Awuor, Cynthia. 2009: Increasing drought in Kenya, in understanding climate change adaptation—Kenya experiencing drought

Government of Kenya (Gok), April, 2010: National climate change response strategy (NCCRS)—Strategies to curb climate change

Food and Agricultural Organization (FAO) 2010: Analysis of climate change and variability risks in the Smallholder sector-Climate change impacting smallholder farmers

International Food Policy Research Institute (IFPRI) October, 2010: Climate variability and climate change: Impacts on Kenyan agriculture-Agriculture being impacted by climate change

International Food Policy Research Institute (IFPRI) 2007: Temperature on the rise—rising temperatures

http://www.ifpri.org/climate-change December, 2014: Reducing hunger, poverty and environmental degradation in the highlands, curbing human activities that contribute to climate change

Government of Kenya (GOK) 2002: A framework for combating desertification in Kenya in the context of the United Nations convention to combat desertification-Curbing desertification in Kenya

Climate Knowledge \& Development Network (CDKN) 4th June, 2012: Agriculture, food security and compatible development case studies-Climate change affecting Agriculture

International Food Policy Research Institute (IFPRI) December, 2010: Food security and climate change, challenges to 2050 and beyond

www.fao.org/docrep/013/11683e.pdf August, 2014: The state of food insecurity in the world—Kenya is food insecure

http://www.igidr.ac.in/pdf/publication/WP-2011-014.pdf December 2014: Climate change, rural livelihoods and agriculture (focus on food security)

http://www.ifpri.org/climate-change December 2014: Securing a place for agriculture at the international climate change—negotiations 2020 panel discussion—Agriculture under threat

ftp://ftp.fao.org/docrep/fao/009/j9271e/j9271e.pdf November, 2014: Adaptation to climate change in agriculture, forestry and fisheries: perspective, framework and priorities_-Adapting agriculture to climate changes

http://www.ipcc.ch/pdf/assessment-report/ar4/syr/ar4 syr.pdf December, 2014: IPCC, Climate change report—Climate change is happening http://www.ipcc.ch/publications_and_data/ar4/wg1/en/ch10.html November, 2014: Global climate change scenarios

http://www.economics-ejournal.org/economics/journalarticles/2013-34 December, 2014: US food security and climate: Agricultural futures—Climate change threatening food security

http://ec.europa.eu/research/research-eu December, 2014: New challenges for agricultural research: Climate change, food security, rural development, agricultural knowledge systems—Climate change posing as a threat to advancement in agriculture

www.ccafs.cgiar.org/commission November, 2014: Food security, farming, and climate change to 2050—Climate change posing as a threat to advancement in agriculture 
jor sources of emissions from the agricultural sector. Firstly, nitrous oxide $\left(\mathrm{N}_{2} \mathrm{O}\right)$ that is apparently the largest source of GHG emission from agriculture naturally produced in the soil through nitrification and denitrification. Also, nitrogen fertilizer application, livestock manure and sewage sludge are some of the agricultural activities that result in emission of nitrous oxide $\left(\mathrm{N}_{2} \mathrm{O}\right)$ that in turn contribute to climate change. In addition, rice production contributes to emissions from anaerobic decomposition of organic matter. Similarly, natural digestive processes in ruminants such as cattle and sheep accounts for majority of methane production. Moreover, manure management includes the handling, storage and treatment of manure, and accounts for 7 percent of agricultural emissions. As a result, methane emissions from enteric fermentation are projected to increase by 32 percent by 2020, with China, Brazil, India, the U.S. and Pakistan being the likely top sources [8].

Apparently, demand for beef and dairy products is expected to rise globally, with sharp increases in consumption and production forecast for the developing world. By 2020, over 60 percent of meat and milk consumption is expected to take place in the developing world, and the production of beef, meat, poultry, pork, and milk is likely to at least double from 1993 levels [9]. Emissions from agriculture are expected to rise due to increased demand for agricultural production, improved nutrition, and the changing dietary preferences of growing populations that favor larger shares of meat and dairy products [9].

Recent estimates show that for each $1^{\circ} \mathrm{C}$ rise in average temperature dry land farm profits in Africa will drop by nearly $10 \%$ [10]. Furthermore, increased evaporation of open water storage would be expected to reduce water availability for irrigation purposes and generation of hydropower. Keep in mind, the Fourth Assessment Report of the Intergovernmental Panel on Climate Change [11] predicts decreasing rainfall in northern and southern Africa, increasing rainfall over the Ethiopian/East African Highlands and a considerable increase in frequency of floods and drought.

Mitigation and a reduction of the carbon dioxide gas in the atmosphere could help in a great way in addressing climate change effects on agriculture yield. In addition, both mitigation and adoption strategies will require support from governments and policy makers. Mitigation basically means measures undertaken with the aim of reducing the amount of emissions so as to enhance absorption capacity of greenhouse gases. Also, carbon storage through crop management "best practices" for example no-till agriculture or reduce the amount of carbon emission into the atmosphere through, burning, tillage, and soil erosion. There are numerous "best" management practices in agriculture that raise SOC, including reducing the amount of bare fallow, restoring degraded soils, improving pastures and grazing land, irrigation, crop and forage rotation, and no-tillage practices [12]. Most important, production of liquid fuels from grains and oilseeds would on a greater way help in mitigation and also cutting down continued dependence and reliance on fossil fuel. Equally important, improving the efficiency of fertilizer application or turning to organic production can decrease the amount of nutrient load and $\mathrm{N}_{2} \mathrm{O}$ emissions.

In general, improved management farm practices for example livestock and manure management, fertilizer management and improved rice cultivation would in a greater way help in reducing green gas emissions into the atmosphere that contribute to climate change. Manure management practices include use of solid covers for storage tanks and lagoons, separating solids from slurry.

Estimations predict that cereal imports will increase in developing countries by 10 to 40 percent by 2080 . Also, Africa will become the region with the highest population of food insecure, accounting for up to 75 percent of the world total by 2080 [5].

Adaptation to climate change is another avenue that can be initiated in order to combat climate change effects. Adaptation to climate change is an adjustment made to a human, ecological or physical system in response to a perceived vulnerability [13]. Adaptation responses can be categorized by the level of ownership of the adaptation measure or strategy. Individual level or autonomous adaptationsare considered to be those that take place in reaction to climatic stimuli (after manifestation of initial impact), that is, as a matter of course and without the directed intervention of any public agency [12]. Adaptation agenda is very large, actions should be undertaken focusing on adaptation capacity, strategies and policy at the national and international levels so as to move adaptation forward. Policy driven or planned adaptationis often interpreted as being the result of a deliberate policy decision on the part of a publicagency, based on an awareness that conditions are about to change or have changed, and that action is required tominimize losses or benefit from opportunities [14].

\section{Food Security and Climate Change}

Food security concerns have been on the international agenda since 1948. Inhabitants of the planet earth have 
the right from hunger and most important, right to a standard of living including food. On the contrary, over the years, diminishing world food supplies coupled with large-scale food shortages have been experienced globally. This has resulted to situations of hunger that calls for increased food production.

Food security is defined as a 'situation when all people, at all times, have physical, social and economic access to sufficient, safe, and nutritious food that meets their dietary needs and food preferences for an active and healthy life' [12]. All dimensions of food security are likely to be affected by climate change. Importantly, food security will depend not only on climate and socio-economic impacts on food production, but also (and critically so) on economic growth, changes to trade flows, stocks, and food aid policy [1].

Food insecurity affects communities around the world because of the reason that poverty prevents assured access to food supplies. Food insecurity also contributes to degradation and depletion of natural resources, migration to urban areas and cross borders, and political and economic instability. Most important, urbanization through rapid population growth, economic recession and structural adjustments policies that have reduced government spending and decreased employment opportunities influence all aspects of food production and consumption. Similarly, high dependence on commercially processed food and market system to acquire food supplies are aspects of food security associated with urban areas. Equally important, it is claimed that the world's resources are adequate to produce enough food for its population. However, current farming practices, including land clearing and inefficient use of fertilizers and organic residues, make agriculture a significant contributor to greenhouse gas emissions on the planet [15].

As global demand for food, fodder and bio energy crops grows, many agricultural systems are depleting soil fertility, biodiversity and water resources. For instance, in many regions there are large gaps between potential and actual crop yields. In addition, inadequate access to productive resources in terms of access to land, security tenure, availability of water and other inputs are major challenges in achieving sustained agricultural productivity. Every year, an estimated 12 million hectares of agricultural land, which could potentially produce 20 million tonnes of grain, are lost to land degradation, adding to the billions of hectares that are already degraded [15]. Consequently, global food prices have risen dramatically in the last few years and are forecast to rise further and become more volatile. Generally, climate change will affect agricultural production, specifically areas suffering from food insecurity are expected to experience more negative impacts. To reduce the effect of climate change on food supplies, livelihoods and economies, we must greatly increase adaptive capacity in agriculture both to long-term climatic trends and to increasing variability as an urgent priority [15].

Majority of African countries are already experiencing considerable water stress as a result of insufficient and unreliable rainfall, changing rainfall patterns or flooding. Climate change impacts including predicted increases in extremes are likely to add to this stress, leading to additional pressure on water availability, accessibility, supply and demand. For Africa, it is estimated that $25 \%$ of the population (approximately 200 million people) currently experience water stress, with more countries expected to face high risks in the future, hence food and water insecurity [1]. Thus, food security remains one of the greatest challenges as a result of water stress. In addition, food security problem is also compounded by poor performance of the agriculture sector and low-value crop production due to re-current droughts and floods hence poverty in many parts of the country. Kenya, particularly its agricultural sector is prone to climate change impacts because of heavy reliance on rain-fed agriculture. Climate change will therefore pose a major food security problem as normal weather patterns are affected. Droughts have severely affected food production over the past two decades. Furthermore, adverse weather conditions and patterns have resulted into reduced planting and crop failure leading to food shortages as well as undermining access to food [5].

Climate change is also likely to have a significant negative impact on agricultural production, prompting output reductions that will greatly affect parts of the developing world. Adaptation, including crop choice and timing, has the ability to partially compensate for production declines in all regions. Finally, climate change adaptation and mitigation have to proceed simultaneously. Since adaptation becomes costlier and less effective as the magnitude of climate changes increases, mitigation of climate change remains essential. The greater the level of mitigation that can be achieved at affordable costs, the smaller the burden placed on adaptation. Policies focused on mitigating GHG emissions, if carefully designed, can help generate a new development strategy; one that encourages the creation of new value in pro-poor investments by increasing the profitability of environmentally sustainable practices. To achieve this goal, it will be necessary to streamline the measurement and enforcement of offsets, financial flows, and carbon credits for investors. It will also be important to enhance global financial facilities and to reform their governance, namely to simplify rules and to increase the funding flows for mitiga- 
tion in developing countries [5].

\section{Conclusions}

Findings from the literature review indicate that climate change poses serious challenges to farmers because of gradual increases in temperature, increased variability in annual rainfall patterns and greater occurrences of extreme events such as drought and floods, hence food insecurity. Indeed, climate change poses great threats to agriculture, which is sensitive to changes in climatic conditions, with outcomes affecting food security, livelihoods and economic prosperity. Therefore, in order to address food security in the agricultural sector, we must address continued food gap, low global food reserves, rising food prices, rising agricultural input prices and needs for increased biofuel production. This means fundamental changes in the agricultural sector so as to adequately address climate change effects. Changes in agricultural systems and their management are needed to enable to adapt to climate change effects, including mitigation pathways. In addition, science based solutions need to be developed and the best delivery mechanisms to be initiated.

The rural poor together with vulnerable farmers in developing countries are in dire need of science based solutions so as to accelerate successful adaptation of agricultural systems to climate change. Such solutions for example practices, technologies and policies will play a major role in enhancing the ability of farmers and other resource users to better manage land, the environment and the most importantly food security.

Although there are viable mitigation technologies in the agricultural sector, especially in developing countries, some key constraints need to be overcome. First, rules of access which still do not credit developing countries for reducing emissions by avoiding deforestation or improving soil carbon sequestration must be changed. Second, operational rules, with their high transaction costs for developing countries and small farmers and foresters in particular, must be streamlined [5].

\section{References}

[1] Ludi, E. (2009) Climate Change, Water and Food Security, Background Note. Overseas Development Institute, London.

[2] Smith, P., Martino, D., Cai, Z., Gwary, D., Janzen, H., Kumar, P., McCarl, B., Ogle, S., O’Mara, F., Rice, C., Scholes, B. and Sirotenko, O. (2001) Agriculture. In: Metz, B., Davidson, O.R., Bosch, P.R., Dave, R. and Meyer, L.A., Eds., Climate Change 2007: Mitigation. Contribution of Working Group III to the Fourth Assessment Report of the Intergovernmental Panel on Climate Change, Cambridge University Press, Cambridge, and New York.

[3] Rosegrant, M.W., Ewing, M., Yohe, G., Burton, I., Huq, S. and Valmonte-Santos, R. (2008) Climate Change and Agriculture, Threats and Opportunities. German Technical Cooperation (GTZ).

[4] UNDP (2008) Fighting Climate Change, Human Solidarity in a Divided World. United Nation Development Programme, New York.

[5] FAO (2002) The State of Food Insecurity in the World 2001. Food and Agricultural Organization, Rome.

[6] Skjei, S. (2005) Using a Fishbone Diagram to Troubleshoot a Satellite Link. The Orbiter, April, 2005.

[7] Adger, W.N., Agrawala, S., Mirza, M.M.Q., Conde, C., O’Brien, K., Pulhin, J., Pulwarty, R., Smit, B. and Takahashi, K. (2007) Assessment of Adaptation Practices, Options, Constraints and Capacity. In: Parry, M.L., Canziani, O.F., Palutikof, J.P., van der Linden, P.J. and Hanson, C.E., Eds., Climate Change 2007: Impacts, Adaptation and Vulnerability. Contribution of Working Group II to the Fourth Assessment Report of the Intergovernmental Panel on Climate Change, Cambridge University Press, Cambridge, 717-743.

[8] IPCC (2007) Summary for Policy Makers. In: Pachauri, R.K. and Reisinger, A., Eds., Climate Change 2007: Synthesis Report. Contribution of Working Groups I, II and III to the Fourth Assessment Report of the Intergovernmental Panel on Climate Change, Intergovernmental Panel of Climate Change, Geneva.

[9] Bates, B.C., Kundzewicz, Z.W., Wu, S.H. and Palutikof, J.P., Eds. (2008) Climate Change and Water. Technical Paper of the Intergovernmental Panel on Climate Change. IPCC Secretariat, Geneva.

[10] Nellemann, C., MacDevette, M., Manders, T., Eickhout, B., Svihus, B., Prins, A. and Kaltenborn, B., Eds. (2009) The Environmental Food Crisis. The Environment's Role in Averting Future Food Crises. A UNEP Rapid Response Assessment. UNDP, Arendal.

[11] UNDP (2006) Global Mitigation of Non-CO2 Greenhouse Gases. Office of Atmospheric Programs, United States Environmental Protection Agency, Washington DC.

[12] Beddington, J., Asaduzzaman, M., Fernandez, A., Clark, M., Guillou, M., Jahn, M., Erda, L., Mamo, T., Van Bo, N., 
Nobre, C.A., Scholes, R., Sharma, R. and Wakhungu, J. (2011) Achieving Food Security in the Face of Climate Change: Summary for Policy Makers from the Commission on Sustainable Agriculture and Climate Change. CGIAR Research Program on Climate Change, Agriculture and Food Security (CCAFS), Copenhagen.

[13] Delgado, C., Rosegrant, M., Steinfeld, H., Ehui, S. and Courbois, C. (1999) Livestock to 2020: The Next Food Revolution. Food, Agriculture, and Environment. Discussion Paper No.28, International Food Policy Research Institute, Washington D.C.

[14] Pittock, B. and Jones, R.N. (2000) Adaptation to What and Why? Environmental Monitoring and Assessment, 61, 9-35. http://dx.doi.org/10.1023/A:1006393415542

[15] Shah, M., Fischer, G. and van Velthuizen, H. (2008) Food Security and Sustainable Agriculture. The Challenges of Climate Change in Sub-Saharan Africa. International Institute for Applied Systems Analysis, Laxenburg. 